\title{
Chapter 8 \\ The Public Perception of the Migration \\ Crisis from the Hungarian Point of View: \\ Evidence from the Field
}

\author{
Bori Simonovits
}

\subsection{Introduction}

Hungary is distinct from most other European countries that have experienced huge migration flows in the past years, both in terms of the political context and the radical change in the volume of migration during 2015. Since the legal and physical closure of the borders in autumn 2015, ${ }^{1}$ significantly fewer asylum seekers have entered Hungary. While in 2015, approximately 177,000 people claimed asylum and more than half a million migrants and asylum seekers crossed Hungary's borders, ${ }^{2}$ in 2016 less than 30,000 asylum claims were registered and in 2017 the number of claims was approximately 3000 (see Appendix 8.1 for further statistics). Furthermore, from a policy perspective, it is important to mention that integration policies have been non-existent since the Hungarian state completely withdrew integration provisions, such as a monthly cash allowance and school-enrolment benefits, on 1 June 2016. Since that date, only NGOs and religious charity organisations have been entitled to provide specific help in the refugee integration process (e.g. assistance in housing, finding employment, learning the Hungarian language or family reunification). Leading human rights organisations warn that this process has brought about significant negative changes in the integration possibilities of forced migrants, and most importantly serious risks of destitution and homelessness, even

\footnotetext{
${ }^{1} 16$ October 2015.

2 "After Hungary completed a fence on its border with Serbia in September, the flow of migrants shifted to Croatia. In all of 2015, the region recorded 764,000 detections, a 16-fold rise from 2014. The top-ranking nationality was Syrian, followed by Iraqis and Afghans." Source: FRONTEX http://frontex.europa.eu/trends-and-routes/western-balkan-route/
}

B. Simonovits $(\bowtie)$

Institute of Intercultural Psychology and Education, Faculty of Education and Psychology,

Eötvös Lóránd University, Budapest, Hungary

e-mail: simonovits.borbala@ppk.elte.hu

(C) The Author(s) 2020

B. Glorius, J. Doomernik (eds.), Geographies of Asylum in Europe and the Role of European Localities, IMISCOE Research Series, https://doi.org/10.1007/978-3-030-25666-1_8 
in case of recognised refugees (Hungarian Helsinki Committee 2017; Amnesty International 2017). As far as the NGOs are concerned, there are certain influential organisations $^{3}$ dedicated to the integration of third country nationals (hereafter TCNs), organising various services for them related to housing, finding employment and learning Hungarian. These services rely partly on funding programmes from the European Union. Furthermore, a significant number of volunteers organised by grassroots organisations took an important role during the 2015 migration crisis, e.g. by providing different forms of help for asylum seekers at various railway stations throughout the country. ${ }^{4}$

Now I turn to briefly discuss Hungary's demographic profile. The following two main features must be emphasised. Firstly, Hungary is a relatively homogenous country both racially and ethnically (the largest ethnic minority is the Roma, who make up 5-6\% of the total population, according to Kemény and Janky 2006), as well as in terms of religion (the overwhelming majority is Christian, mostly Catholic). Secondly, the proportion of the migrant population is low; the number of immigrants per 1000 inhabitants remains well below that in most Western European countries. The crude immigration rate-the number of immigrants related to the size of the population in the destination country-has been fluctuating between 1.8 and 2.6 since 2000, whereas in the majority of Western European countries this rate is over 5 or in some cases even over 10 per thousand (Gödri 2015).

In this paper ${ }^{5} \mathrm{I}$ aim to assess different components and levels of mass migrationrelated fear based on the theoretical framework of integrated (later re-labelled intergroup) threat theory developed by Stephan and Stephan (1993; Stephan et al. 2009). My main research question is why symbolic threats from migrants crossing or settling in Hungary are as dominant as realistic threats, based on national (Simonovits 2016) and international quantitative research results (Messing and Ságvári 2018) that rely on Round 7 of the European Social Survey. This chapter is structured in the following way: in Sect. 8.2 I briefly discuss the most recent Hungarian political developments relevant to our topic. Section 8.3 presents the theoretical framework and aims to introduce the concepts of intergroup threat theory, while Sect. 8.4 discusses the empirical strategy. Section 8.5 is devoted to an overview of the most important survey results measuring xenophobic attitudes, while qualitative results are presented in Sect. 8.6. Finally, the conclusion (Sect. 8.7) reflects on the most

\footnotetext{
${ }^{3}$ Most importantly, Menedék Association should be mentioned in this regard: https://menedek.hu/ en

${ }^{4}$ The main motivations of the aid work and the composition of the volunteers at both the organizational and individual level has been analysed by Bernát et al. (2016) and Feischmidt and Zakariás (2019).

${ }^{5}$ This chapter has been written in the framework of a Postdoctoral Research Grant (No: 121095) entitled "A Meta Analysis of Intergroup Contact Theory Based on Surveys, Controlled Experiments and Case Studies-With a Special Focus on Immigrants Living in Europe" provided by the National Research, Development and Innovation Fund in Hungary. I am also grateful to the Artemisszió Foundation for letting me use the data gathered through the comprehensive research on migration-related attitudes in Hungary in 2017, as part of the project entitled "ThreeZ: Impact, Independence, Integration" (funded by the OSI under the project number OR-2016-29608).
} 
relevant findings from the quantitative and qualitative data analysis as well as the limitations of the research.

\subsection{Political Context}

As far as the political context is concerned, during the 2015 migration crisis the official communication of the Hungarian government purposefully refrained from using the words 'asylum seekers' and 'refugees', and preferred to use the terms 'illegal migrants' and 'economic migrants', in order to frame public discourse. In opposition to this, certain left-wing political parties, as well as certain research institutes (e.g. Publicus Research), ${ }^{6}$ intentionally used the terms 'asylum seekers' and 'refugees' for this heterogeneous group of people to frame the public discourse the other way around. This dichotomy in the perception of the different migrant groups was reinforced by the field research, as most participants in the focus group discussions emphasised the need to distinguish the two terms: while migrants were mostly perceived as illegal, refugees were perceived as a deserving and vulnerable group. For the crisis of 2015, we use the term migration crisis, as it can be best described as a mixed flow, according to the UNHCR (2015), comprising various kinds of migrants who left their countries on a forced or voluntary basis.

Further discussing the political context, it is important to mention that throughout 2017 the Hungarian government ran a billboard campaign against George Soros' pro-immigration stance, as a follow-up to an anti-immigrant billboard campaign introduced in spring 2015. The campaign-featuring Soros's smiling face with the words "Don't let Soros have the last laugh"-resulted in sporadic incidents of antiSemitic graffiti throughout the country. ${ }^{7}$ One of the major issues in the campaign for Hungary's 2018 parliamentary election, which was dominated by the governing party, was the possible dangers of mass migration affecting Europe. Furthermore, Prime Minister Viktor Orbán recently drew a parallel between Hungary's Roma community in the north-eastern city of Miskolc, where the percentage of the Roma population has been very high since the 1970s, and the recent migration crisis.

There was a time when people from the outside en masse immigrated into this city. And you remember what happened. The people of Miskolc experienced what happened then. ... Yet those people who moved to Miskolc came from the territory of Hungary. Now you imagine what will happen when people who in their culture, customs, and views are completely different from us arrive from outside of the country. ${ }^{8}$

\footnotetext{
${ }^{6} \mathrm{http}: / /$ www.publicus.hu/en/

${ }^{7} \mathrm{We}$ used these billboards as supplementary research materials in our focus group sessions. You can see examples in the following direct links: https://goo.gl/images/6GVFQb, https://goo.gl/ images/KNBc9B

${ }^{8}$ The strategy of hate: Viktor Orbán in Miskolc (4 March 2018): Hungarian Spectrum. http://hungarianspectrum.org/2018/03/04/the-strategy-of-hate-viktor-orban-in-miskolc/ Accesses 23 March 2018.
} 
It is obvious to anyone with any recollection of recent Hungarian history that the prime minister meant the Roma citizens of Hungary in the quotation above.

For a better understanding of the Hungarian context, it is important to note that influential scholars (Róna-Tas 2015; Erös 2016) have framed the mass migrationrelated public discourse within the context of a moral panic. ${ }^{9}$ A moral panic is the process of arousing social concern over an issue, usually through the work of "moral entrepreneurs" (people initiating the panic who create a clear message and set the agenda) and the mass media. This process can be described as intensive fear and a high level of anxiety raised by news transmitted by the mass media that is responded to by government measures, and thus it has a special relevance to our subject matter. Both Erös and Róna-Tas argue that a moral panic was stoked by the Hungarian government, relying on strong national feelings, and xenophobic attitudes closely related to welfare chauvinism and scapegoating. Furthermore, Barlai and Sik introduce the concept of the Moral Panic Button as a Hungarian Trademark (2017), which they define as a complex set of state-propaganda techniques, including various forms of manipulation such as 'national consultation', the 'quota referendum', Parliamentary elections and overlapping waves of billboard, TV and radio ad campaigns. The aim of using the moral panic button, in their understanding, is to win popularity by framing and manipulating the political discourse in the public sphere.

\subsection{Theoretical Framework}

The Intergroup Threat Theory (Stephan et al. 2009) ${ }^{10}$ is a widely used theoretical framework to examine anti-immigrant sentiments in European societies (see for example Velasco-Gonzalez et al. 2008) as well as in the USA (see for example Croucher et al. 2013). The theory-incorporating several theoretical perspectives on stereotypes and prejudices - suggests that four basic types of threat may lead to prejudice. First, there are realistic threats at the material, economic and political levels, focusing on the competition over material and economic group interests. Realistic threats are threats that pose a danger to the in-group's well-being, including threats to physical safety or health, threats to economic and political power, as well as threats to the existence of the group. Second are symbolic threats, which in contrast to realistic threats are based on perceived group differences in values, norms, and beliefs (Stephan and Stephan 1993). The basis of these perceptions is that out-groups (in this case immigrants) often have differing world views than dominant groups. Third is negative stereotyping, which is expectations of how a member of an out-group will behave, often related to feelings of threat or fear. Fourth is intergroup anxiety, which is a feeling of being personally threatened during interactions with out-group members.

\footnotetext{
${ }^{9}$ The original concept was developed by Cohen in the early 1970s; for the Hungarian application and contextual background, see, for example, Kitzinger (2000).

${ }^{10}$ Originally labelled as Integrated Threat Theory and developed by Stephan and Stephan in 1993.
} 
In the analysis below the primary focus is on the distinction between realistic and symbolic threats, as this distinction is crucial to understanding anti-immigrant sentiments in contemporary Hungary. Analysing the Hungarian case, it is important to note that not only symbolic, but also realistic threats may be understood at the level of perception; the kernel of truth (in this case the actual "danger" of immigration) is not that relevant in our understanding. Following the interpretation of VelascoGonzalez et al. (2008), the core issue here is the perceived competition over scarce resources (e.g. jobs, houses, social welfare), and the perception that these resources are threatened by outsiders.

The concept of realistic threat is closely related to the idea of welfare chauvinism, as both concepts assess the perceived competition of scarce resources (such as labour market positions and social services), and the majority's perception is that these resources are threatened by outsiders, i.e. immigrants. In Hungary-and also in the neighbouring Central-Eastern European countries-welfare chauvinism ${ }^{11}$ and scapegoating have been measured to be central elements of anti-immigrant sentiments (see more on the Hungarian context by Enyedi et al. 2004; Simonovits and Szeitl 2016). Beyond that, previous research has confirmed both in the European context (Bizman and Yinon 2001; Velasco-González et al. 2008; Stephan and Stephan 1993) and the US context (Croucher et al. 2013) that Muslim immigrants are perceived both as a realistic and as a symbolic threat to the dominant-mostly Christian-Western cultures. Recent empirical research-both in the international and in the Hungarian context-has underlined that asylum seekers with a Christian background are more welcomed than those with a Muslim background.

Hainmueller and Hopkins (2012) and Bansak et al. (2016) have recently tested empirically how economic, humanitarian, and religious concerns affect attitudes towards asylum seekers in the US, and in certain European countries. Both studies were based on a survey experimental research design and tested for the influence of an extended list of randomised immigrant attributes on generating support for admitting immigrants. Both the US and the European results underlined that host societies prefer immigrants of higher social status, i.e. more highly educated immigrants and in jobs with higher status. In contrast, they view asylum seekers unfavourably, seeing them as people who do not plan to work, have entered their country without authorization, or do not speak English. Regarding the religion of asylum seekers, a high level of anti-Muslim sentiment was measured (in comparison to antiChristian or anti-agnostic sentiment) by Bansak et al. (2016). Boda and Simonovits (2016) showed using Hungarian data that respondents at the later phase of the migration crisis (in January 2016) tended to accept asylum seekers being persecuted due to belonging to a Christian denomination twice as likely as asylum seekers who were being persecuted due to belonging to a Muslim denomination (23\% vs $9 \%$ ).

\footnotetext{
${ }^{11}$ Welfare chauvinism refers to the idea that welfare benefits should be restricted to certain groups, particularly to the natives of a country, as opposed to immigrants. The term was first used by Jørgen Goul Andersen and Tor Bjørklund in Denmark and Norway in 1990.
} 


\subsection{Data and Methods}

This study relies on both quantitative and qualitative data. The quantitative data analysis is based on TÁRKI's long-term research on xenophobia and attitudesfrom national representative surveys - while the qualitative part is based on joint research of TÁRKI and Artemisszió Foundation ${ }^{12}$ in the framework of what is called the "ThreeZ" project. In 2017, all together 12 focus group discussions were held in five different places across Hungary. The analytical framework of these group discussions was developed by a research team consisting of anthropologists and sociologists. ${ }^{13}$ Our main aim was to better understand what people think about the increasing level of mass migration in Europe, how they feel about migrants with different racial and ethnic origins, and most importantly how they conceive the different aspects of threats related to mass migration. By applying qualitative methods, we aimed to better understand what was in people's heads, as this method enables researchers to gain first-hand experience with people forming different opinions on migration.

The group discussions were organised in two waves, as they slightly differed in terms of their research focus. In the first wave of our empirical research (implemented in March 2017) four main interrelated topics were discussed: (i) general problems and public issues in Hungary, (ii) solidarity in general and specifically towards refugees, (iii) attitudes towards different types of migrants-asking respondents to differentiate between asylum seekers, refugees and labour migrants - and (iv) personal experiences with migrants. In the second wave (carried out in June 2017) we concentrated more on the different types of perceived threats related to mass migration into Hungary and Europe; more specifically, we discussed in the groups (i) directly perceived threats, (ii) welfare chauvinism and labour-related threats, and (iii) national and cultural isolationism. The socio-demographic composition of the focus groups that participated in the two waves can be found in Appendix 8.2. ${ }^{14}$

During the selection of the target locations, our primary criteria was to find locations affected by the migration crisis at different levels, as the main goal of these group interviews was to explore how citizens-in different geographical locations - respond to the migration crisis and to xenophobic political discourse spread all around the country via the mass media, national consultations, and billboard campaigns. We selected three locations (Keszthely, Vecsés and Salgótarján) that had not been affected at all by the recent migration flow, alongside Szeged, as an example of a town heavily affected by the 2015 migration crisis (as it is situated near the Serbian-Hungarian border), and finally Budapest, as the capital of Hungary was part

\footnotetext{
${ }^{12} \mathrm{http}: / /$ artemisszio.blog.hu/

${ }^{13}$ Here I want to thank, for the collaborative work, Teréz Pataki, Diána Szántó (Artemisszió Foundation), Bence Ságvári (Hungarian Academy of Sciences, Centre for Social Sciences), Anikó Bernát and Blanka Szeitl (TÁRKI, Social Research Institute).

${ }^{14}$ Further details on the sampling process, the screening questionnaire and the focus guidelines can be sent upon request.
} 
of the main migration route in 2015 , with its three main railway stations operating as transit zones that summer. The compositions of the groups were homogenous in terms of level of education and mass migration-related attitudes (we differentiated between very dismissive and less dismissive respondents, as we could hardly find any people with pro-immigration views), but heterogeneous in terms of gender; the selection process was based on a screening questionnaire. ${ }^{15}$

The focus group guidelines were designed in line with the theoretical framework described above, asking specific questions on the different types of mass migrationrelated threats beyond the general questions related to the experiences of the recent mass migration. I developed the analytical framework of the focus group discussions using the theoretical approach of Stephan and Stephan (1993), distinguishing the different levels of anti-immigrant threats.

\subsection{Anti-Immigrant Attitudes at the National Level (Quantitative Analysis)}

Intergroup relations between the majority population and immigrant minorities are actually a hot issue in the European context. In international comparison-based on European Social Survey Round 7 and Round 8 data, and a Gallup World Poll carried out in 2016-Hungary is one of the worst-performing countries in terms of social distance and welcoming attitudes towards migrants (Messing and Ságvári 2018; Gallup 2017). Generally it can be stated that not only Hungary, but most Eastern European countries (e.g. Bulgaria, Croatia, Estonia, Czech Republic, Latvia, Slovakia) are among those least accepting of migrants (MEDAM 2018).

Based on a recent survey on xenophobic attitudes in Hungary-carried out by TÁRKI in January 2017-the level of xenophobia has reached an all-time high (60\% of the total population), and xenophilia has practically disappeared (Fig. 8.1).

Analysing results of the European Social Survey-Round 7, the fieldwork for which was carried out in 2014 and 2015-on anti-immigrant sentiments, Messing and Ságvári (2018) concluded that different components of fear (welfare, labour market, crime, cultural and religious) are the most important basis of anti-immigrant views. The following five factors correlated most strongly with less negative attitudes towards mass migration in all examined countries at the individual level: high levels of interpersonal and institutional trust, tertiary education, contact with different racial or ethnic groups, and feeling safe in the dark. Beyond the micro-level factors, the authors concluded that the following macro-level factors most explained the differences in attitudes towards migration: "people in countries with a large migrant population, with a high level of general and institutional trust, low level of corruption, a stable, well performing economy and high level of social cohesion and

\footnotetext{
${ }^{15}$ For the exact location and composition of the groups see Appendix 8.2.
} 


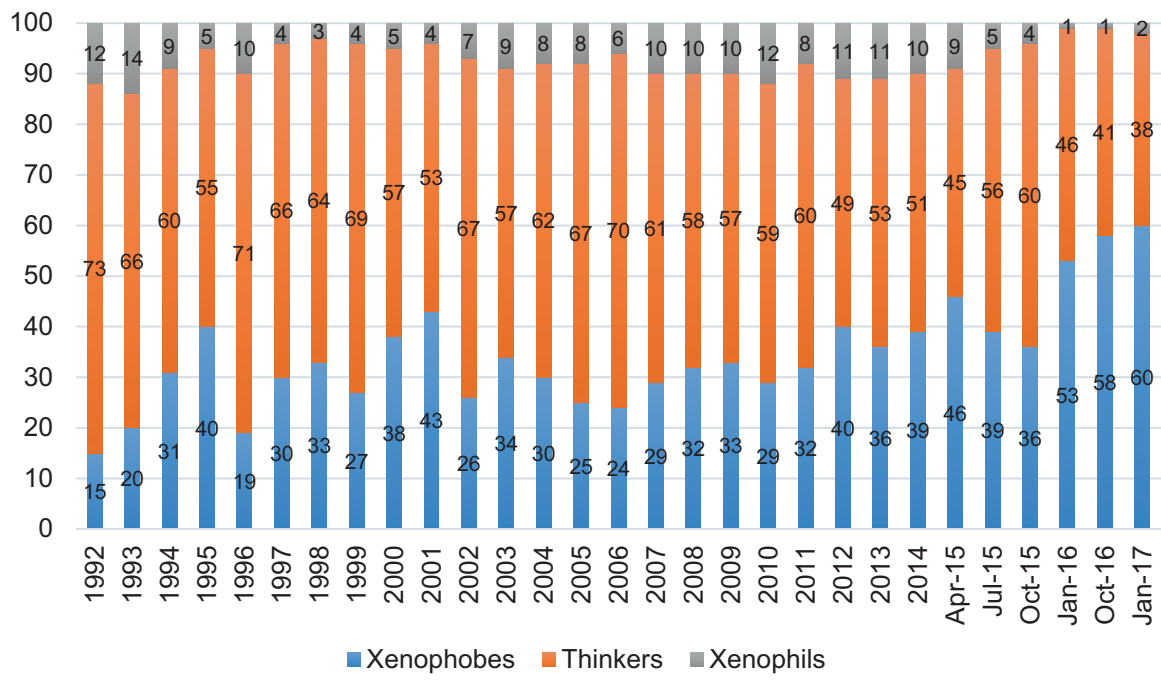

Fig. 8.1 The ratio of xenophobes, xenophiles and thinkers (I labelled as "xenophobes" are those respondents who would not admit any asylum seekers into Hungary, as "xenophiles" those who would admit all asylum seekers into Hungary, and "thinkers" as those who would consider admitting asylum seekers into the country) 1992-2017 (in per cent). (Source of data: Tárki Omnibus survey 1992-2017)

inclusion (including migrants) fear migration the least according to the data from 2014-15” (Messing and Ságvári 2018: 28).

To the best of my knowledge, relatively little attention has been paid to examining attitudes to refugees and asylum seekers in Hungary, but much more to attitudes towards migrants (e.g. the 7th Round of the European Social Survey), even though these two groups raise different concerns, especially in today's European context. The questions we used in our survey from $2016^{16}$ addressed both groups, as the increased flow included various kinds of migrants, best labelled as a 'mixed flow' according to the UNHCR (2015).

In line with the theoretical framework presented above, we tried to separate between the two types of threats by using a simple set of anxiety-related questions. We measured realistic threat with two interrelated questions assessing the majority's perceived anxiety related to the volume and 'irregularity' (i.e. undocumented status) of the current migration flow arriving into Hungary and Europe. To measure symbolic threats, we used two questions to assess perceived anxiety related to the

\footnotetext{
${ }^{16}$ The fieldwork was completed in mid-January 2016, 2 months after the Paris terror attack (13 November 2015) and right after a series of sexual assaults, allegedly perpetrated by migrants, in several German cities on New Year's Eve. The survey block on migration-related attitudes-a part of TÁRKI, Hungarian Social Research Centre's regular Omnibus survey-was based on a representative sample (by age, gender, place of residence and level of education) of 1000 adult respondents.
} 
different cultural and religious backgrounds of migrants arriving into Hungary and Europe.

Figure 8.2 illustrates that the level of perceived threat was very high in all aspects measured, and that levels of threats are somewhat higher about the irregularity and volume of the current migration flow (realistic threat: 92-93\%) than the level of fear related to the different cultural and religious background of the migrants (level of symbolic threat: 89-90\%). The results of my principal component analysis (2016) underlined that the two types of mass migration-related threats were strongly related as well, and the correlation analysis revealed most of the respondents think in a similar way concerning the perceived cultural and symbolic threats to Hungary.

In the same survey we also measured how Hungarians felt about asylum seekers with different reasons for flight. Figure 8.3 shows changes in attitudes towards asylum seekers' different reasons for flight, in the order of how welcomed a given group was in October 2015 and January 2016. It is clear that respondents made a clear distinction between on the one hand those who had left their country due to (civil) war, had fled due to hunger or natural catastrophe, or with the aim of family reunion, and on the other hand those claiming asylum for other reasons such as being part of an oppressed ethnic, national or religious minority; the level of acceptance of this second group was significantly lower. In the case of those who had left their home country due to lack of work, the percentage of acceptance was very low, which means the great majority of the Hungarian adult population is not welcoming towards them at all, in line with both the Hungarian government's and the European Union's current asylum policy. A more elaborated analysis on the social basis of the symbolic and realistic threats can be found in Simonovits (2016).

Analysing the trend, it is clear that welcoming attitudes dropped dramatically between October 2015 and January 2016, in most cases by half, regardless of

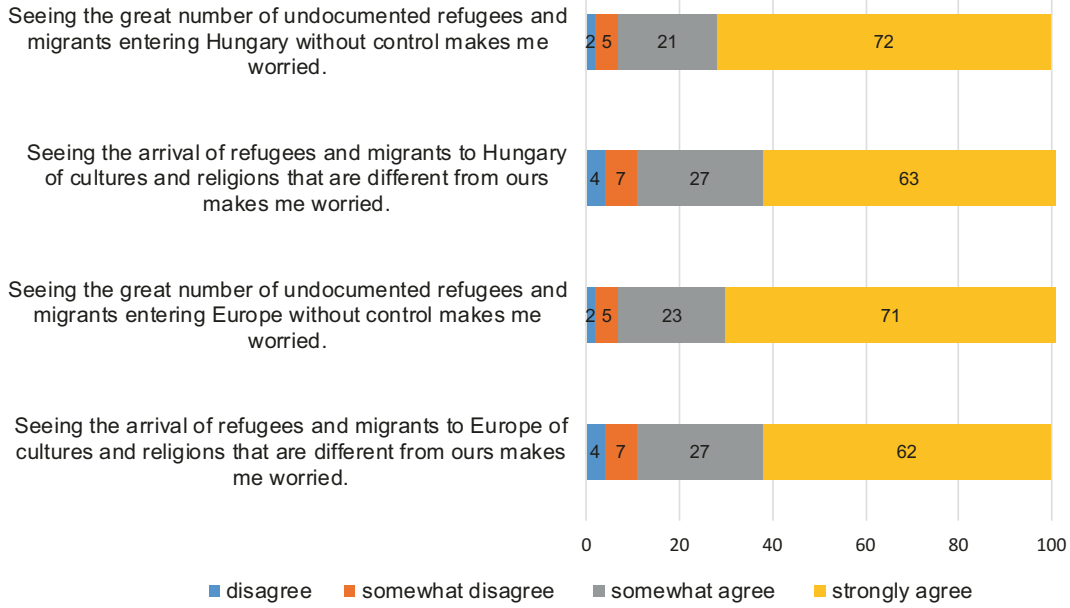

Fig. 8.2 Different components of the perceived threat from the current migration flow into Europe and Hungary (in per cent, approx. $\mathrm{N}=980$ ). (Source: Boda and Simonovits 2016) 


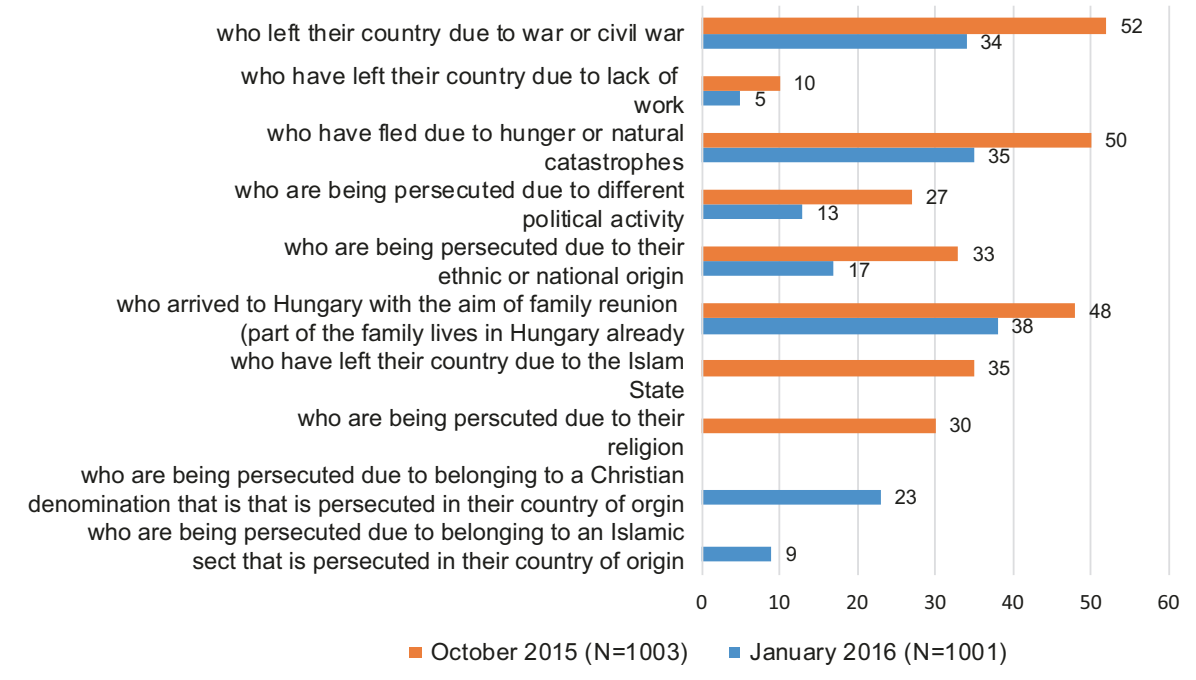

Fig. 8.3 Reasons for flight: Acceptance of different reasons for flight, in order of being welcomed ('From among the asylum seekers, should Hungary admit those...?' - those who answered "yes", in per cent, in October 2015 and January 2016). (Source: Boda and Simonovits 2016)

whether the refugees' reason for flight was war or religion. While in October 2015 more than half of the population would have accepted asylum seekers who left their country due to war or civil war, in January only one third of the respondents had a welcoming attitude towards them. The numbers are similar in the case of hunger and natural catastrophes as well (where the level of acceptance dropped from 50\% to $35 \%$ ), and family reunion (decreased from $48 \%$ to $38 \%$ ). Moreover, the level of acceptance in the case of being persecuted due to one's ethnic or national origin dropped by half, from $33 \%$ to $17 \%$, as well as in the case of being persecuted due to one's political activity (from $27 \%$ to $13 \%$ ). The level of acceptance in the case of lack of work was almost non-existent in January 2016, while in October 2015 it was twice as high: $10 \%$. This is perfectly in line with the Hungarian government's and the European Union's recent asylum policy. (See more on that in the qualitative analysis in Sect. 8.4).

It is worth mentioning that in the second wave (January 2016), religious affiliation was divided into two separate questions (Christians and Muslims) in order to see if there is a difference in response to each. While roughly every fourth respondent $(23 \%)$ would welcome asylum seekers who are being persecuted due to belonging to a Christian denomination, only $9 \%$ responded positively in the case of Muslims.

Before shifting our attention to the qualitative results, it is worth to take a look at the Hungarian respondents' personal contacts with migrants. Based on our representative survey, the proportion of those who personally knew migrants was very low at both times we measured during the migration crisis: in October 2015 only $3 \%$ 
30

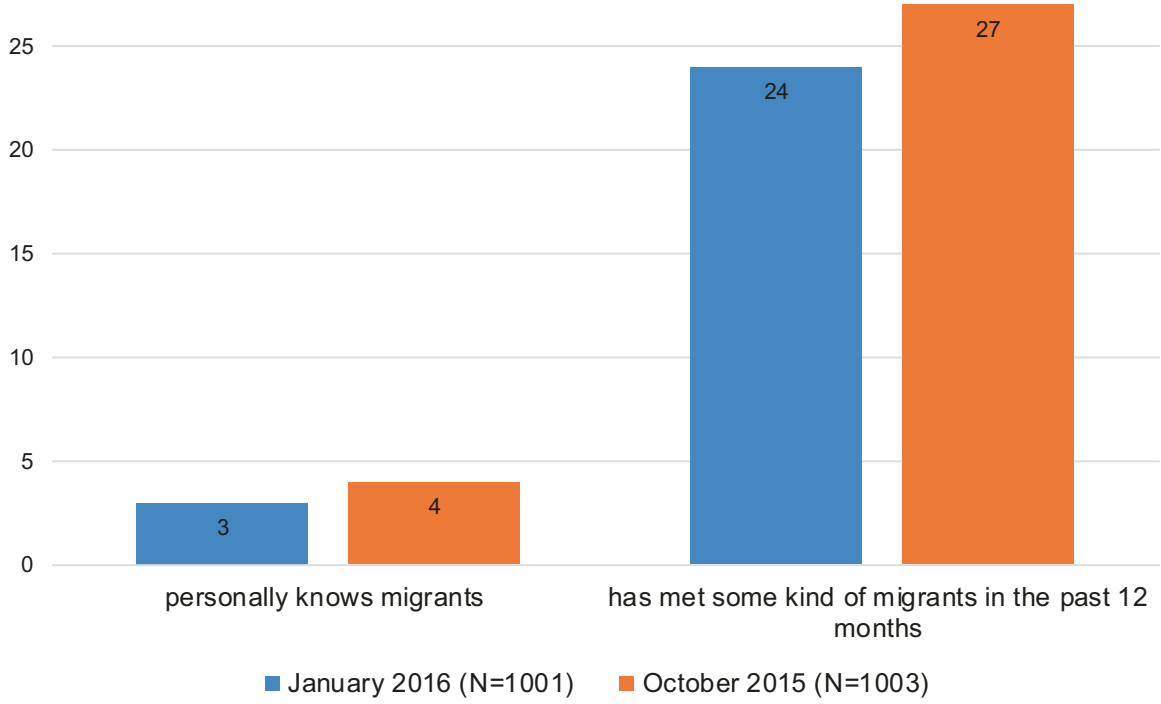

Fig. 8.4 The proportion of those who personally knew migrants and those who had met some kind of migrant in the past 12 months (in October 2015 and January 2016). (Source: Tárki omnibus survey October 2015 and January 2016)

of the Hungarians said that they personally knew any kind of migrant, and in January 2016 this proportion was $4 \%$ (Fig. 8.4).

Surprisingly, the proportion of those who had met some kind of migrant in the past 12 months was high (24\% in October and 27\% in January), suggesting that people interpreted this question broadly, i.e. presumably even those who only saw or passed by migrants in the past year answered "yes" to this question.

\subsection{Anti-Immigrant Attitudes at the Local Level (Qualitative Analysis)}

For the qualitative analysis, it must be noted that the focus groups were organised in the political climate described above, during the different waves of billboard campaigns against immigration and George Soros' pro-immigration stance. For the qualitative analysis below, I have organised the results in the following way: based on the scripts of the 12 focus groups, I first briefly discuss the respondents' level of knowledge regarding mass migration, and then focus on the different aspects of mass migration-related threats (illustrative quotations are summarised in Tables 8.1 and 8.2 by location type). 
Table 8.1 Types of the perceived threats: realistic and symbolic threats expressed in the focus group discussions, by type of location (March and June 2017)

\begin{tabular}{|c|c|c|c|}
\hline $\begin{array}{l}\text { Type of the } \\
\text { perceived threat }\end{array}$ & $\begin{array}{l}\text { Szeged (Serbian- } \\
\text { Hungarian border } \\
\text { area) }\end{array}$ & $\begin{array}{l}\text { Budapest (its } 3 \\
\text { railway stations and } \\
\text { their surroundings } \\
\text { were affected to a } \\
\text { large extent) }\end{array}$ & $\begin{array}{l}\text { In locations not affected by } \\
\text { the } 2015 \text { migration crisis }\end{array}$ \\
\hline \multicolumn{4}{|l|}{ Realistic threats } \\
\hline $\begin{array}{l}\text { Safety (crime, } \\
\text { terrorism, } \\
\text { diseases) }\end{array}$ & $\begin{array}{l}\text { "We were afraid of } \\
\text { going out on the } \\
\text { street" } \\
\text { "I did not feel safe at } \\
\text { the border" } \\
\text { "I was afraid of } \\
\text { catching diseases } \\
\text { from them" } \\
\text { "The mass at the } \\
\text { border was } \\
\text { frightening" }\end{array}$ & $\begin{array}{l}\text { "It is not the older } \\
\text { generation, but the } \\
\text { kids of the Pakistani } \\
\text { taxi driver that might } \\
\text { blow us up" }\end{array}$ & $\begin{array}{l}\text { "Within Hungary, only } \\
\text { Budapest might be a } \\
\text { potential target for } \\
\text { terrorists" } \\
\text { "We definitely need the } \\
\text { border fence, though it is } \\
\text { not strong enough" }\end{array}$ \\
\hline Labour market & $\begin{array}{l}\text { "They do not want to } \\
\text { work" } \\
\text { "We do not need } \\
\text { them as they do not } \\
\text { have special skills" }\end{array}$ & & $\begin{array}{l}\text { "They [the Chinese } \\
\text { entrepreneurs] do not pay } \\
\text { taxes" } \\
\text { "Their products are of bad } \\
\text { quality" }\end{array}$ \\
\hline $\begin{array}{l}\text { Welfare (social } \\
\text { services) }\end{array}$ & $\begin{array}{l}\text { "The wars and ethnic } \\
\text { conflicts of the } \\
\text { Middle East are not } \\
\text { our problem" }\end{array}$ & $\begin{array}{l}\text { "Mass migration } \\
\text { means a huge burden } \\
\text { to Europe" } \\
\text { "We have the Roma, } \\
\text { we do need other } \\
\text { burdens, such as } \\
\text { immigrants" }\end{array}$ & $\begin{array}{l}\text { "Hungary's welfare system } \\
\text { is not strong enough to } \\
\text { accommodate large amounts } \\
\text { of migrants" }\end{array}$ \\
\hline $\begin{array}{l}\text { Volume of } \\
\text { migration, } \\
\text { proportion of } \\
\text { minority groups in } \\
\text { the receiving } \\
\text { countries }\end{array}$ & $\begin{array}{l}\text { The alleged high } \\
\text { fertility rate is } \\
\text { perceived to be a } \\
\text { problem; } \\
\text { Most respondents } \\
\text { were against an } \\
\text { undocumented } \\
\text { stream of migration }\end{array}$ & $\begin{array}{l}\text { "Too many } \\
\text { immigrants have } \\
\text { arrived in Europe and } \\
\text { also in Hungary" } \\
\text { "They have too many } \\
\text { kids" }\end{array}$ & $\begin{array}{l}\text { "There are certain districts } \\
\text { in Budapest, where there are } \\
\text { a lot of them [migrants]" } \\
\text { "Their fertility rate is much } \\
\text { higher than ours, and this is } \\
\text { the problem" } \\
\text { "If family reunification is } \\
\text { allowed, they would bring } \\
8-10 \text { (!) wives and their kids } \\
\text { with them" }\end{array}$ \\
\hline \multicolumn{4}{|l|}{ Symbolic threats } \\
\hline Religious threats & $\begin{array}{l}\text { Muslim religion and } \\
\text { religious fanaticism: } \\
\text { "Christians could } \\
\text { assimilate better" } \\
\text { "Only whites should } \\
\text { be accepted into } \\
\text { Hungary" }\end{array}$ & $\begin{array}{l}\text { "They should respect } \\
\text { our religion and us" } \\
\text { "Islam aims to destroy } \\
\text { Christianity and } \\
\text { Western civilization" }\end{array}$ & $\begin{array}{l}\text { "They are Islamists, they } \\
\text { would behave towards us as } \\
\text { they are used to; i.e. they } \\
\text { rape kids and cut the hands } \\
\text { off of } 8 \text {-year-old children" } \\
\text { "They stick to their religion" }\end{array}$ \\
\hline
\end{tabular}


Table 8.1 (continued)

\begin{tabular}{|c|c|c|c|}
\hline $\begin{array}{l}\text { Type of the } \\
\text { perceived threat }\end{array}$ & $\begin{array}{l}\text { Szeged (Serbian- } \\
\text { Hungarian border } \\
\text { area) }\end{array}$ & $\begin{array}{l}\text { Budapest (its } 3 \\
\text { railway stations and } \\
\text { their surroundings } \\
\text { were affected to a } \\
\text { large extent) }\end{array}$ & $\begin{array}{l}\text { In locations not affected by } \\
\text { the } 2015 \text { migration crisis }\end{array}$ \\
\hline Cultural threats & $\begin{array}{l}\text { "Their culture and } \\
\text { their habits are the } \\
\text { problems" } \\
\text { "Because of their } \\
\text { culture they would } \\
\text { never assimilate" } \\
\text { "They do not respect } \\
\text { our girls and } \\
\text { women" }\end{array}$ & $\begin{array}{l}\text { "They have their own } \\
\text { rules. It is impossible } \\
\text { to make them adapt to } \\
\text { the European culture" } \\
\text { "They look } \\
\text { dangerous" }\end{array}$ & $\begin{array}{l}\text { "They would not learn our } \\
\text { language" } \\
\text { "If } 3 \text { or } 4 \text { families live in the } \\
\text { same street, with their same } \\
\text { culture and habits, they } \\
\text { won't adapt to our } \\
\text { behavioural patterns" } \\
\text { "They are violent" }\end{array}$ \\
\hline
\end{tabular}

Note: the author's analytical framework is based on the theoretical approach developed by Stephan and Stephan originally in 1993

Table 8.2 Perceived positive impacts of mass migration, articulated in the focus group discussions, by type of location (March and June 2017)

\begin{tabular}{|c|c|c|c|}
\hline Areas & $\begin{array}{l}\text { Szeged (Serbian- } \\
\text { Hungarian border } \\
\text { area) }\end{array}$ & $\begin{array}{l}\text { Budapest (with the largest } \\
\text { immigrant population) }\end{array}$ & $\begin{array}{l}\text { In locations not affected by } \\
\text { the } 2015 \text { migration crisis }\end{array}$ \\
\hline $\begin{array}{l}\text { Labour } \\
\text { market }\end{array}$ & - & $\begin{array}{l}\text { "The Turks in the kebab shop } \\
\text { also work hard (from } 10 \text { a.m. to } \\
11 \text { p.m.)" }\end{array}$ & $\begin{array}{l}\text { "Those who work [i.e. } \\
\text { Arabic doctors, Chinese } \\
\text { entrepreneurs] can stay" } \\
\text { "The Chinese immigrants } \\
\text { are hardworking" }\end{array}$ \\
\hline Religious & Not mentioned & Not mentioned & Not mentioned \\
\hline Cultural & $\begin{array}{l}\text { "Only new tastes } \\
\text { and music, nothing } \\
\text { else is needed" }\end{array}$ & $\begin{array}{l}\text { "Let's have a colourful Europe, } \\
\text { but not at the cost of me being } \\
\text { afraid to leave my home after } \\
\text { dark." }\end{array}$ & $\begin{array}{l}\text { "Restaurants run by } \\
\text { migrants are acceptable, but } \\
\text { nothing more" } \\
\text { "We do not want to change } \\
\text { our Coat of Arms" } \\
\text { "The Chinese are okay. } \\
\text { They have the money to } \\
\text { move here" }\end{array}$ \\
\hline
\end{tabular}

\subsubsection{General Knowledge and Attitudes About Migration and Integration}

Even though the overwhelming majority of the focus group participants had hardly any personal experiences with migrants and asylum seekers, they formed quite definite and categorical views on recent immigrant groups entering Europe as well as on those who arrived into Europe in the past decades. They differentiated quite easily between forced and labour migrants, and expressed a bit more empathy towards forced migrants who had to leave their homes because of political persecution, as 
well as towards Christians who had to flee their homes due their religion (in line with the quantitative results presented above).

Generally, most of the respondents had an overwhelmingly negative view of both the recent migration flow affecting Europe and the integration process. In line with the aforementioned quantitative results, focus group participants also thought that too many migrants had arrived in Europe and Hungary without a proper screening and documentation process. As far as immigrant populations in Western European countries are concerned, the participants were able to enumerate some of the countries that had experienced huge migration flows in the past decades and recently. They seemed to be well-informed about the so-called no-go zones in certain European cities as obvious signs of failure of integration policies.

It turned out that most respondents had been informed via public media channels-echoing primarily the official views of the Hungarian government's antiimmigrant rhetoric — as well as via the taxpayer-funded billboard campaign all over Hungary. ${ }^{17}$

Most of the respondents had some basic knowledge of the main migration trends into Europe, i.e. they were aware of the fact that certain Western European countries-most frequently Germany was mentioned — had experienced a huge migration flow since the 1960s. They were also quite certain that generally it is not the first generation of immigrants, but members of the second and third generation who might become terrorists. The dominant view was that Hungary is a small country compared to most Western European states, and thus unlikely to become a primary target of terrorist attacks. "They do not even know where we are [Hungary]; there are bigger fish in Europe" (Budapest Group, June 2017). Some of the respondents shared the view that "it is not the migrants who are responsible for the terrorist events, but bigger forces, like the European and American world powers" (Budapest Group, June 2017). In contrast, some of the respondents placed the primary emphasis on the individual dispositions (the case of Breivik was mentioned) as well as on the effects of socialisation (i.e. if someone is raised in a deprived neighbourhood), thus they did not agree with the total exclusion of Muslim migrants. We could identify a type of reasoning, making use of the social-psychological phenomenon of relative deprivation: "in Belgium, for example, second and third generation migrants don't work; they see their neighbours doing better than them... so they go bombing" (Vecsés Group, June 2017).

Comparing the Hungarian towns and cities, most of the respondents agreed that Budapest has been the most affected by migratory movements in the past decades. They claimed that "there are certain districts of Budapest where there are a lot of migrants" (Keszthely Group, June 2017). Some of the participants emphasised that the growing number of immigrants poses a challenge to public safety, and they also find this tendency problematic from a cultural point of view, i.e. they argued that if too many migrants live in a locality, their culture will become dominant. Even

\footnotetext{
${ }^{17}$ See more on the content analysis of the Hungarian media by Bernáth and Messing (2015) as well as a comparison between the Austrian and Hungarian media coverage, and an analysis of the news coverage of three symbolic events in the migration crisis, by Bernáth and Messing (2016).
} 
though we did not ask the participants to estimate the actual ratio of migrant populations in Hungary, they seemed to be overestimating the real numbers. Again, it has to be noted here that in Hungary the proportion of migrants is very low; the foreignborn population makes up 1-2\% of the total population, the overwhelming majority of which are ethnic Hungarians who migrated from the neighbouring countries that used to be part of Hungary before 1920 (Gödri 2015).

Discussing the different types of migrant groups, most of the interviewees differentiated between (i) the old migrants who had lived in Hungary for decades and worked mainly as medical doctors or in other professional positions (most of which having arrived in Hungary from Northern African or Arab countries in the 1970s as students), or run their own local businesses (i.e. Asian immigrants, primarily from China or Vietnam), and (ii) the "newcomers" who are mostly perceived to be as neither useful for the economy (i.e. they do not have the proper skills) nor truly vulnerable people eligible for social welfare. We learnt this primarily in the focus groups of lower status respondents according to whose reoccurring reasoning there were Hungarians who were more in need than the Syrian refugees "wearing Nike shoes and having smartphones" (Salgótarján Group, March 2017). The following idea also emerged in several groups: "if someone is a refugee, thus fleeing from a war zone, why doesn't he stay in his home country and fight?" (Salgótarján Group, March 2017). They also argued that it is not Europe's responsibility to let the refugees in, as on their way Turkey was the first peaceful country.

\subsubsection{Perceived Migration-Related Threats}

Discussing welfare services provided to recognised refugees, the overwhelming majority expressed views that can be best labelled as welfare chauvinistic. It again has to be noted that the Hungarian government completely withdrew from integration services provided to beneficiaries of international protection in summer 2016. At certain points of the group discussions, participants drew a parallel between the Roma and the migrants in terms of both groups being "lazy" and "a threat to public safety" as well as tending to conserve their own identities and being unwilling to assimilate into Hungarian society. These ideas were primarily articulated in Salgótarján, situated in one of the most economically depressed areas of Hungary with a significant Roma population. It has to be mentioned here that Prime Minister Victor Orbán also pointed to alleged similarities between the Roma and the immigrants a number of times during the migration crisis.

As far as labour market threats are concerned, we learnt of two basic ideas. Regarding the old migrants, the hardest criticism was articulated about Chinese and Vietnamese businessmen who do not pay taxes and sell bad quality goods. However, there was not a perfect agreement in this regard: some of the respondents liked cheap Asian products. The newcomers, in contrast, were criticised for their "laziness" and for their lack of language (Hungarian and English) and professional skills. 
As far as symbolic threats are concerned, the Prime Minister warned the Hungarian Parliament as well as visiting Polish politicians about Europe's possible dark future if they continued to allow more immigrants into the old continent:

We may lose our European values — our very identity—by degrees, like the live frog allowing itself to be slowly cooked to death in a pan of water. Quite simply there will be more and more Muslims, and Europe will be transformed beyond recognition. If we are unable to change things now, we can predict with sufficient mathematical accuracy-all one needs are some mathematical calculations-what Europe's cities will look like in two or three decades (Viktor Orbán 2016). ${ }^{18}$

Opinions in the focus groups were formed in line with these ideas, repeating that Hungary does not need people with other cultural and religious backgrounds (see selected quotations in Table 8.1).

Summing up, the qualitative results underscored the quantitative results, as both realistic and symbolic threats by Muslim immigrants are perceived to be high in contemporary Hungary, and letting in a great amount of people with unknown identities is seen as posing a serious risk to the receiving society. Most of the arguments given by the focus group participants echoed the concepts of the government, in terms of terrorism, contagious diseases, as well as immigrants imposing a huge burden on the welfare state. As far as cultural threats are concerned, lack of language skills is perceived to be a crucial problem. Focus group participants repeatedly emphasised that the basic problem is that migrants tend to arrive in groups and live in blocks in European cities, making integration nearly impossible. Some of them added that even though they make up only a minority of the population, they tend to dominate the majority population.

In contrast, we could hardly find any positive or neutral opinions related to migration into Hungary or Europe. In Szeged, the city with direct experience of the 2015 migration crisis, we did not record a single positive statement related to immigration (see Table 8.2).

To sum up, we could hardly find any positive views with regards to the effects of migration. Most interviewees were in favour of the strict immigration policy introduced by the Hungarian government, including the $170 \mathrm{~km}$-long border fence. Furthermore, they proposed building a wall similar to the one at the US-Mexico border as a more effective tool against irregular migrants.

\subsection{Conclusion}

To understand the Hungarian case, it is crucial to re-emphasise that a new era in asylum policy began in 2015, at the beginning of the recent migration crisis, which manifested itself in a different approach to the provision of reception conditions as

\footnotetext{
${ }^{18}$ See the whole speech on the official page of the Hungarian Government at: http://www.kormany. hu/en/the-prime-minister/the-prime-minister-s-speeches/prime-minister-viktor-orban-s-address-inparliament-before-the-start-of-daily-business20160912.
} 
well as a dismantling of integration services. ${ }^{19}$ As a result, in the last few years, the permanent, better-equipped reception facilities have been replaced with temporary centres offering less favourable reception conditions. Since 2016, asylum seekers have been systematically detained in transit zones, which are in remote locations, built into the border fence. Furthermore, the vulnerabilities of asylum seekers have been systematically ignored-most importantly, unaccompanied minors over 14 years of age are also detained in the transit zones. From early 2016 the monthly cash allowance that asylum seekers were given to spend how they wished, as well as the school-enrolment benefits previously provided to asylum seekers, were withdrawn. ${ }^{20}$

These developments have had an increasingly serious effect on asylum seekers trying to find refuge in Hungary. Moreover, the dismantled integration services and further negative changes in family unification rules have discouraged recognised refugees and beneficiaries of subsidiary protection from staying in Hungary for the long term. So I can conclude that the pronounced aim of the Hungarian government has been to stop the immigration of irregular TCNs into Hungary. The abovementioned policy changes have been accompanied by an extensive anti-immigrant campaign since early 2015, and an elaborated moral panic (related to the threats of mass migration) in Hungarian society. In light of these developments, it is not surprising that the empirical research could barely find support for refugee reception among the Hungarian population.

The quantitative and qualitative results were mostly in line with each other. The overwhelming majority of the Hungarian population is absolutely dismissive towards any kind of migrants (either forced or voluntary). According to the latest representative survey results, 6 out of 10 Hungarians would not let any asylum seekers into the country, and during the focus group discussions there were rarely narratives in favour of either labour migration or forced migration into the country. Based on the complex analysis conducted here, I can conclude that perceived threatsboth realistic and symbolic - have real consequences, regardless of whether or not the perceptions of threats are accurate.

Most Hungarians were able to differentiate between different types of migrant groups. There seemed to be a contradiction however: on the one hand-based on the quantitative results-respondents felt more solidarity towards forced migrants; on the other hand - based on the qualitative results—out of the main immigrant groups, the Chinese, were always mentioned as most acceptable. One reasoning behind that was that Chinese immigrants do not impose a burden on the Hungarian welfare state (as they run their own businesses) and they are not perceived to be a threat either in a realistic or a cultural way. Asked about forced migrants from war zones or those fleeing from natural catastrophes, roughly one third of the respondents expressed

\footnotetext{
${ }^{19}$ Similar tendencies were also observed in other European countries (see Chaps. 3, 4 and 5 of this volume).

${ }^{20}$ For more details see the Hungarian Helsinki Committee (2017).
} 
their theoretical solidarity, but based on the qualitative results the overwhelming majority of the Hungarian population did not express welcoming attitudes towards these groups either.

All in all, it is obvious that migrants who are Muslims are rejected to a large extent, as they are perceived by Hungarians as presenting both a realistic and a symbolic threat. The overwhelming majority of the group interviewees shared the opinion that Islam is a violent and domineering religion (i.e. aiming at taking control), and that Muslim migrants are unable to integrate into European societies. Our qualitative results showed how the key messages of the official public discourse were echoed in the groups, as well as how successfully and efficiently the moral panic has reached its target population. However, it has to be mentioned that the findings derived from the qualitative research have low external validity, as the number of observations was rather low (approx. 100 respondents) and not representative of the Hungarian adult population.

\section{Appendices}

\section{Appendix 8.1}

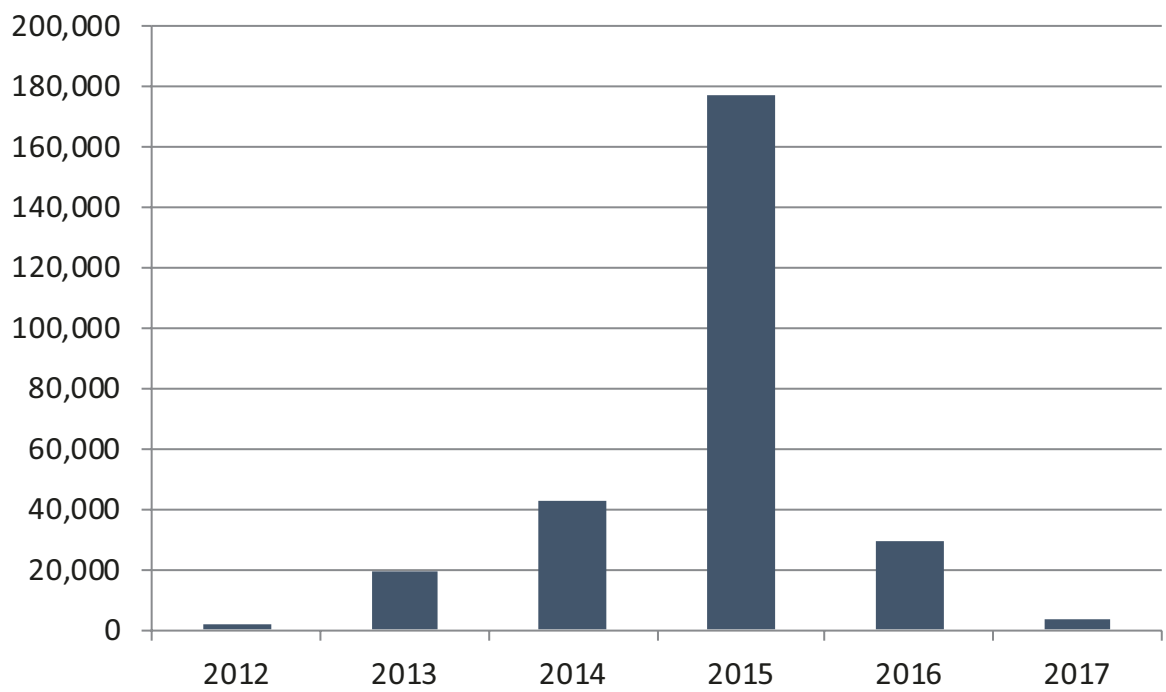

Number of asylum applications (2009-2017). (Source: Hungarian Helsinki Committee 2017) 


\section{Appendix 8.2}

\section{Composition and Locations of the Focus Groups Held in Hungary in 2017}

Wave 1: Composition and locations of the focus groups, in Hungary in March 2017

\begin{tabular}{l|l|l|l|l|l|l}
\hline No. & Name of the location & $\begin{array}{l}\text { Date of the } \\
\text { focus group }\end{array}$ & Gender & Age & $\begin{array}{l}\text { Social } \\
\text { status }\end{array}$ & $\begin{array}{l}\text { Attitude towards } \\
\text { migration }\end{array}$ \\
\hline 1. & Budapest & 8 March & heterogeneous & $60+$ & middle & very dismissive \\
\hline 2. & Budapest & 8 March & heterogeneous & $25-60$ & high & rather dismissive \\
\hline 3. & $\begin{array}{l}\text { Salgótarján } \\
\text { (north-eastern part of } \\
\text { Hungary) }\end{array}$ & 14 March & heterogeneous & $25-35$ & low & very dismissive \\
\hline 4. & $\begin{array}{l}\text { Salgótarján } \\
\text { (north-eastern part of } \\
\text { Hungary) }\end{array}$ & 14 March & heterogeneous & $35-60$ & middle & rather dismissive \\
\hline 5. & $\begin{array}{l}\text { Szeged (Serbian } \\
\text { border zone) }\end{array}$ & 10 March & heterogeneous & $25-35$ & middle & very dismissive \\
\hline 6. & $\begin{array}{l}\text { Szeged (Serbian } \\
\text { border zone) }\end{array}$ & 10 March & heterogeneous & $35-60$ & low & rather dismissive \\
\hline
\end{tabular}

${ }^{a}$ Based on a complex definition of the level of education and the financial status of the respondent. Screening questionnaires assessing both social status and attitudes towards immigration can be sent upon further request

Wave 2: Composition and locations of the focus groups, in Hungary in July 2017

\begin{tabular}{l|l|l|l|l|l|l}
\hline No. & Name of the location & $\begin{array}{l}\text { Date of the } \\
\text { focus } \\
\text { group }\end{array}$ & Gender & Age & $\begin{array}{l}\text { Level of } \\
\text { education }\end{array}$ & $\begin{array}{l}\text { Attitude } \\
\text { towards } \\
\text { migration }\end{array}$ \\
\hline 7. & Budapest & 24 July & heterogeneous & $60+$ & middle & very dismissive \\
\hline 8. & Budapest & 24 July & heterogeneous & $25-60$ & high & $\begin{array}{l}\text { rather } \\
\text { dismissive }\end{array}$ \\
\hline 9. & $\begin{array}{l}\text { Vecsés (in the } \\
\text { agglomeration of } \\
\text { Budapest) }\end{array}$ & 26 July & heterogeneous & $25-35$ & low & very dismissive \\
\hline 10. & $\begin{array}{l}\text { Vecsés (in the } \\
\text { agglomeration of } \\
\text { Budapest) }\end{array}$ & 26 July & heterogeneous & $36-60$ & middle & $\begin{array}{l}\text { rather } \\
\text { dismissive }\end{array}$ \\
\hline 11. & $\begin{array}{l}\text { Keszthely (south- } \\
\text { western region of } \\
\text { Hungary) }\end{array}$ & 27 July & heterogeneous & $25-35$ & middle & very dismissive \\
\hline 12. & $\begin{array}{l}\text { Keszthely (south- } \\
\text { western region of } \\
\text { Hungary) }\end{array}$ & 27 July & heterogeneous & $36-60$ & low & $\begin{array}{l}\text { rather } \\
\text { dismissive }\end{array}$ \\
\hline
\end{tabular}

${ }^{a}$ Based on a complex definition of the level of education and the financial status of the respondent. Screening questionnaires assessing both social status and attitudes towards immigration can be sent upon further request 


\section{The Geographical Location of the Focus Groups Held in Hungary in 2017}

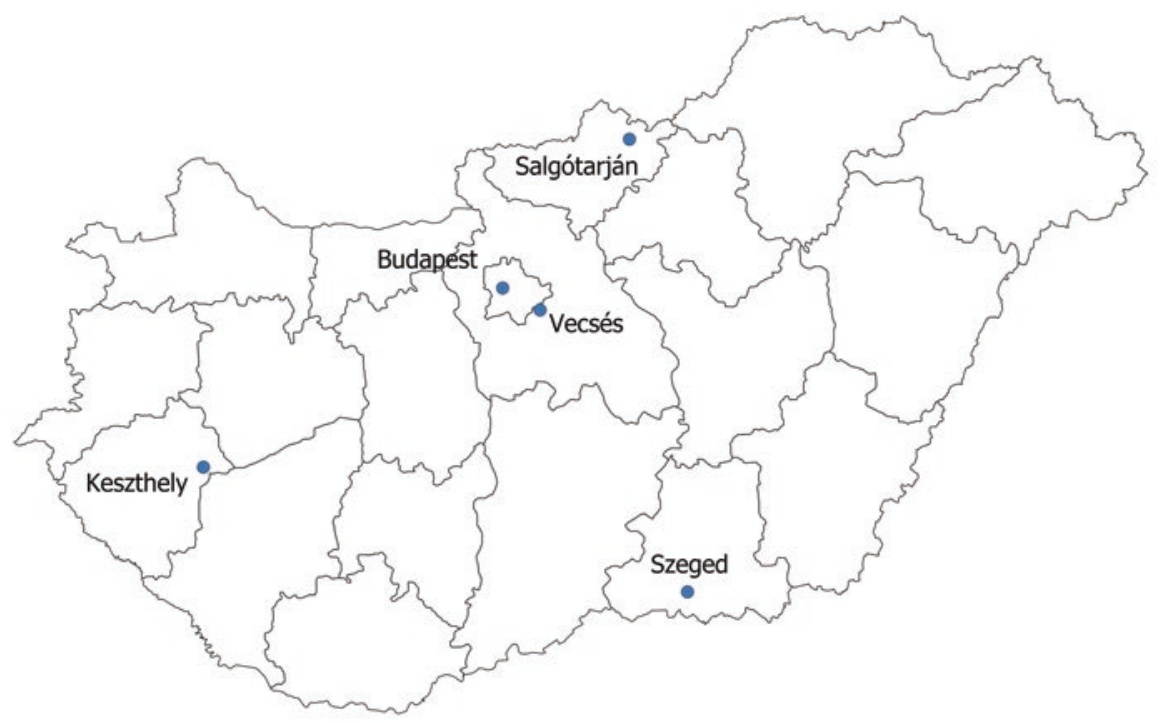

GeoData from gadm.org (counties) and OpenStreetMap (cities)

\section{References}

Amnesty International. (2017). Hungary: Legal amendments to detain all asylum-seekers a deliberate new attack on the rights of refugees and migrants. Public Statement. https://www.amnesty. org/download/Documents/EUR2758552017ENGLISH.pdf. Accessed 30 Mar 2018.

Andersen, J. G., \& Bjørklund, T. (1990). Structural change and new cleavages: The Progress parties in Denmark and Norway. Acta Sociologica, 33(3), 195-217.

Bansak, K., Hainmueller, J., \& Hangartner, D. (2016). How economic, humanitarian, and religious concerns shape European attitudes toward asylum seekers. Science, 354(6309), 217-222.

Barlai, M., \& Sik, E. (2017). A Hungarian trademark (a "Hungarikum"): The moral panic button. In M. Barlai, C. Griessler, B. Fähnrich, \& M. Rhomberg (Eds.), The migrant crisis: European perspectives and national discourses (pp. 147-168). Zürich: LIT.

Bernát, A., Kertész, A., \& Tóth, F. M. (2016). Solidarity reloaded: Volunteer and civilian organizations during the migration crisis in Hungary. Review of Sociology of the Hungarian Sociological Association, 26(4), 29-52.

Bernáth, G., \& Messing, V. (2015). Bedarálva. A menekültekkel kapcsolatos kormányzati kampány és a tőle független megszólalás terepei. Médiakutató, 2015/4, 7-17.

Bernáth, G., \& Messing, V. (2016). Infiltration of political meaning-production: Security threat or humanitarian crisis? The coverage of the refugee 'crisis' in the Austrian and Hungarian media in early autumn 2015 (Working paper). https://cmds.ceu.edu/sites/cmcs.ceu.hu/files/attachment/article/1041/infiltrationofpoliticalmeaningfinalizedweb.pdf. Accessed 30 Mar 2018.

Bizman, A., \& Yinon, Y. (2001). Intergroup and interpersonal threats as determinants of prejudice: The moderating role of in-group identification. Basic and Applied Social Psychology, 23(3), 191-196. 
Boda, D., \& Simonovits, B. (2016). Reasons for flight. Does it make a difference? In B. Simonovits \& A. Bernát (Eds.), The social aspects of the 2015 migration crisis in Hungary (pp. 48-57). Budapest: TÁRKI.

Croucher, S. M., Homsey, D., Brusch, E., Buyce, C., DeSilva, S., \& Thompson, A. (2013). Prejudice toward American Muslims: An integrated threat analysis. Journal of Intercultural Communication, 14(32), 1-8.

Enyedi, Z., Fábián, Z., \& Sik, E. (2004). Nőttek-e az előítéletek Magyarországon? Antiszemitizmus, cigányellenesség és xenofóbia változása az elmúlt évtizedben. In T. Kolosi, I. Tóth, \& G. Vukovich (Eds.), Társadalmi Riport 2004 (pp. 375-399). Budapest: TÁRKI.

Erős, F. (2016). Summary of a public lecture by Ferenc Erős titled as "A morális pánikot a kormány szította, és a politika táplálja". (Moral panic is induced by the government and fed by the politics) Magyar Narancs 4, November 2016.

Feischmidt, M., \& Zakariás, I. (2019). Politics of care and compassion: Civic help for refugees and its political implications in Hungary-A mixed-methods approach. In M. Feischmidt, L. Pries, \& C. Cantat (Eds.), Refugee protection and civil society in Europe (pp. 59-99). Cham: Palgrave.

Gallup. (2017). New index shows least-, most-accepting countries for migrants. http://news.gallup. com/poll/216377/new-index-shows-least-accepting-countries-migrants.aspx. Accessed $30 \mathrm{Mar}$ 2018.

Gödri, I (2015). International migration. In J. Monostori, P. Öri, \& Zs. Spéder (Eds.), Demographic portrait of Hungary 2015. http://demografia.hu/en/publicationsonline/index.php/demographicportrait/issue/view/326. Accessed 20 Mar 2018.

Hainmueller, J., \& Hopkins, D. J. (2012). The hidden American immigration consensus: A conjoint analysis of attitudes toward immigrants. American Journal of Political Science, 59(3), 529-548.

Hungarian Helsinki Committee. (2017). Two years after: What's left of refugee protection in Hungary? Information note by the Hungarian Helsinki Committee. http://www.helsinki.hu/ wp-content/uploads/Two-years-after_2017.pdf. Accessed 23 Mar 2018.

Kemény, I., \& Janky, B. (2006). Roma population of Hungary 1971-2003. In I. Kemény (Ed.), Roma of Hungary: East European monographs (pp. 170-225). New York: Atlantic Research and Publications.

Kitzinger, D. (2000). A morális pánik elmélete. Replika, 40, 23-48.

MEDAM. (2018). Assessment report on asylum and migration policies in Europe. Flexible solidarity: A comprehensive strategy for asylum and immigration in the EU. http://www.medammigration.eu/wp-content/uploads/2018/05/MEDAM-assessment-report_2018.pdf. Accessed 30 June 2018.

Messing, V., \& Ságvári, B (2018). Looking behind the culture of fear. Cross-national analysis of attitudes towards migration. Friedrich Ebert Foundation. http://library.fes.de/pdf-files/bueros/ budapest/14181.pdf. Accessed 25 Mar 2018.

Orbán, V. (2016). Prime minister Viktor Orbán's address in parliament before the start of daily business. Hungarian Government. http://www.kormany.hu/en/the-prime-minister/the-primeminister-s-speeches/prime-minister-viktor-orban-s-address-in-parliament-before-the-start-ofdaily-business20160912. Accessed 28 Mar 2018.

Róna-Tas, Á. (2015). Interview with Róna-Tas, Ákos titled as "Ez a morális pánik sokkal veszélyesebb, mint egy mecset Zuglóban, vagy egy imám a Parlamentben”. (This type of moral panic is much more dangerous than a mosque in Zugló or an imam in the Parliament). 444. hu. http://444.hu/2015/10/02/ez-a-moralis-panik-sokkalveszelyesebb-mint-egy-mecset-zugloban-vagy-egy-imam-a-parlamentben/. Accessed 2 Oct 2015.

Simonovits, B. (2016). Realistic and symbolic threats. The social basis of mass-migration related fear in contemporary Hungary. Review of Sociology of the Hungarian Sociological Association, 4(26), 53-74.

Simonovits, B., \& Szeitl, B. (2016). Menekültekkel és migrációs politikával kapcsolatos attitűdök Magyarországon és nemzetközi összehasonlításban. In T. Kolosi \& I. G. Tóth (Eds.), Társadalmi Riport 2016 (pp. 420-440). Budapest: TÁRKI. 
Stephan, W. G., \& Stephan, C. W. (1993). Cognition and affect in stereotyping: Parallel interactive networks. In D. M. Mackie \& D. L. Hamilton (Eds.), Affect, cognition, and stereotyping: Interactive processes in group perception (pp. 111-136). Orlando: Academic.

Stephan, W. G., Ybarra, O., \& Rios, K. (2009). Intergroup threat theory. In T. D. Nelson (Ed.), Handbook of prejudice, stereotyping, and discrimination (pp. 43-59). New York: Taylor and Francis.

UNHCR. (2015). Mixed migration. A 10-point plan of action. http://www.unhcr.org/mixed-migration.html. Accessed 8 Mar 2018.

Velasco-González, K., Verkuyten, M., Weesie, J., \& Poppe, E. (2008). Prejudice towards Muslims in the Netherlands: Testing integrated threat theory. British Journal of Social Psychology, 47, $667-685$.

Open Access This chapter is licensed under the terms of the Creative Commons Attribution 4.0 International License (http://creativecommons.org/licenses/by/4.0/), which permits use, sharing, adaptation, distribution and reproduction in any medium or format, as long as you give appropriate credit to the original author(s) and the source, provide a link to the Creative Commons license and indicate if changes were made.

The images or other third party material in this chapter are included in the chapter's Creative Commons license, unless indicated otherwise in a credit line to the material. If material is not included in the chapter's Creative Commons license and your intended use is not permitted by statutory regulation or exceeds the permitted use, you will need to obtain permission directly from the copyright holder.

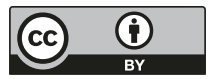

